\title{
In Memoriam: Éva Vámos (22 May 1950 - 25 July 2015)
}

Prof. Dr. Éva Katalin Vámos passed away on July 25, 2015 in Budapest, at the age of 65 after a long-lasting severe illness. European science has lost one of its most active historians of science and technology, one of the founders and former President of the Commission on Women in Science and Gender Studies (Women's Commission) of the Division of History of Science and Technology of the International Union of the History and Philosophy of Science and Technology (IUHPS/DHST).

Éva Vámos was born on May 22 in 1950 in Budapest into an intellectual family. Her father Endre Vámos, an engineer, and her mother Lilly Vámos, a biochemist, actively supported

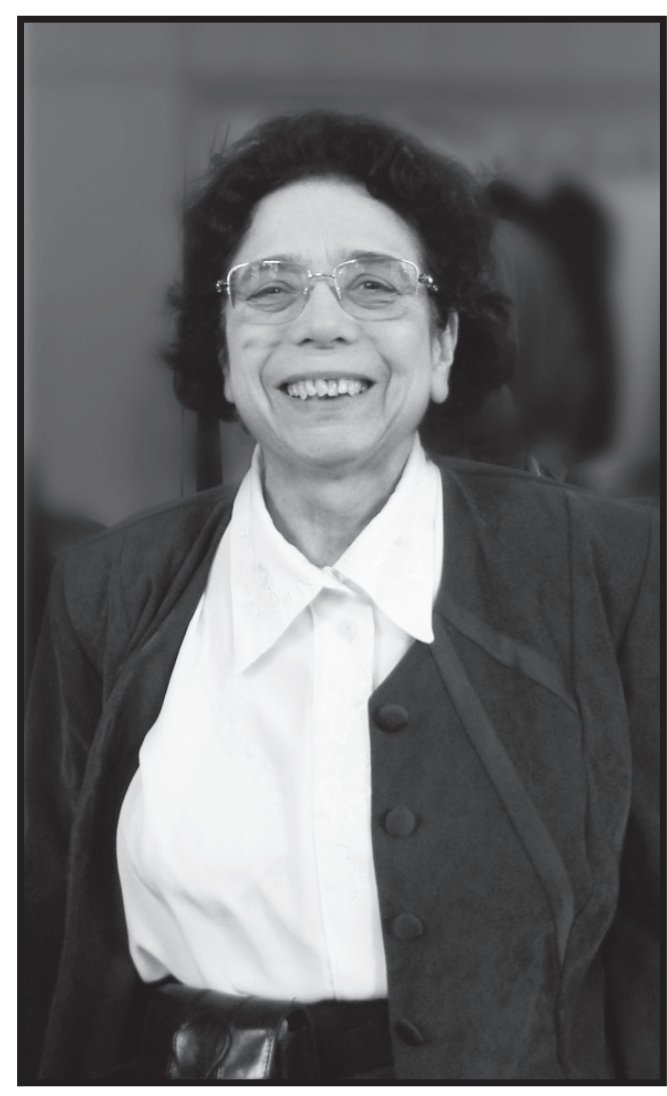
Éva's scientific activities. Young Éva received an excellent education, not only in science but also in history, literature, and philosophy; she spoke English as well as German. She studied chemistry at the Technical University in Budapest, received her PhD, and in 2003 completed her habilitation. From 1973 until her untimely death, she had been affiliated with the National Museum for Science and Technology in Budapest. Here she started her academic career as a curator and close collaborator and disciple of the Museum Director General, the foremost Hungarian historian of chemistry Ferenc Szabadváry (1923-2006). In 1994, she became his successor as 
director general of the Museum for Science, Technology and Transport, serving more than ten years in this position. She became a leading personality among Hungarian historians of science and museologists and one of their foremost representatives on the international scene.

Éva Vámos contributed significantly to museological theory and practice, history of chemistry and chemical industry, and history of women in science. She investigated, for instance, eighteenth- to twentieth-century social history of chemistry in Hungary, German-Hungarian relations in chemistry and chemical industry from 1876 to 1914, Liebig's Hungarian contacts, and chemical memorials in Hungary. Her results were published in more than 200 articles and edited volumes. She participated in major international book projects such as Women Scholars and Institutions (2004), Creating Networks in Chemistry: The Founding and Early History of Chemical Societies in Europe (2008), and European Women in Chemistry (2011). The gender perspective of history of science had attracted her long before it became an acknowledged discipline and not accidentally one of her last papers described the "Girls' Day in a Hungarian Museum" (2013).

Éva Vámos belonged to the group of women historians of science who decided to launch the Women's Commission of the IUHPS/DHS in August in 1981 at the XVI International Congress of History of Science in Bucharest. She also stood at the cradle of the Working Party of History of Chemistry of the European Association for Chemical and Molecular Sciences (WP EuCheMS), founded by her tutor Prof. Ferenc Szabadváry in 1977. Since 1977, she had been a tireless organizer and excellent host of numerous scientific meetings both of the Women's Commission and the WP EuCheMS in Veszprém, Budapest, Sopron and other places in Hungary. Her international organizing activities culminated in 2009 when she was the chairperson of the Local Organizing Committee and co-chair of International Programme Committee of the XXIII International Congress of History of Science and Technology held in Budapest from July 28 to August 2, 2009.

Éva Vámos also served the international community of historians of science and museologists in a number of other capacities, particularly as corresponding (2005) and effective (2010) member of the International Academy of the History of Science, assistant secretary general of the IUHPS/DHST in 2005-2009, member of the Scientific Council of the European Society for History of Science, and secretary of the International Committee for Museums and Collections of Science and Technology. 
Her colleagues and friends will always remember Éva as a warm and gracious person, generous in her appreciation of others' achievements and unfailingly helpful to their aspirations. Those who knew her will sorely miss her and never forget her support and advice, her energetic encouragement of research and cooperation. Those who had the good fortune to meet Éva Vámos privately, will never forget her versatile knowledge and intelligence, broad-based views, friendly behavior and kindness. She will always be in our memories as a unique person and a good friend.

\section{Annette B. Vogt}

Max Planck Institute for the History of Science, Berlin, Former President of the Women's Commission 